higher nutritive value than white bread, probably partly on account of this conversion of the starch, which is a process indispensable to its digestion if it has not happened before it is eaten; and, of course, the whole-meal bread is richer in inorganic salts by the retention of the husk.

And it must not be supposed that rye bread is of necessity "black"; a bread that is lighter in colour than our brown bread can be made from rye flour, the depth of colour being dependent upon the treatment.

So far, then, there is not the smallest reason to suppose that black bread is inferior as a nutritive food to white bread, but rather the contrary.

Passing from the consideration of the nitrogenous (vegetable fibrin) constituents, rye contains as much or more starch and fatty matter as wheat. It contains more lime, about the same amount of magnesia, a good deal more silica, and slightly less phosphoric acid.

As the phosphates of lime and magnesia are needed for the calcification of bones and teeth, there is little to choose in this respect between a whole-meal wheaten bread and rye bread, both being superior to white bread. Formerly it was supposed that teeth of poor quality were actually deficient in lime salts, but this has been found not to be the case. Good teeth, whatever may be their chemical difference, and this has not been ascertained as yet, are unquestionably associated with good general nutrition in the growing person, and, of course, an adequate supply of lime and magnesia is essential to their formation. It should be added that the differences between samples of the same cereals are considerable, being apparently dependent upon the season, soil, and other conditions, so that in many cases the analyses show discrepant results.

But a consideration of the chemistry of the different breads gives no support to the idea that black bread is an inferior article of diet, and the German peasant is not to be pitied for having to use it. In texture it is moister, a little more sticky and doughy, does not get stale so soon, and it might not be wholly to the taste of those accustomed to wheaten bread, at all events at first. It is good food, nevertheless, and those accustomed to it often actually prefer it.

During the Crimean war the Russian prisoners in the hands of the French did not thrive, but after, on the advice of a Russian surgeon, they were given the black bread to which they were accustomed they did much better.

The political orator is not too particular about his facts so long as he thinks they will serve his turn, and the allegations made about black bread have been, to say the least, wanting in scientific accuracy, and so may be classed with much else that is heard from electioneering platforms as calculated, whether with intent or from ignorance, to convey a perfectly false impression.

\section{COMMANDER PEARY'S EXPEDITION TO THE NORTH POLE.}

NO geographical goal has been so long and 1 ardently desired as the North Pole. The glamour of the Dark Continent, the mystery of the South Polar lands, the lure of Potosi and Golconda, have never touched the popular imagination like the attraction of the North Pole. The whale and seal hunters of the seventeenth and eighteenth centuries developed the art of Arctic travel; while the Eskimo, the polar fauna, and the heroism of the knights of the frozen seas, kept an undue share of popular geographical interest "North where the bergs careen."
The commercial hopes that led to the search for the North-West Passage and the Franklin tragedy for a while made the Arctic Archipelago the centre of popular interest, but the North Pole, as a fixed spot, as definite as the winning post of a race, has kept its own as the goal most prized by sporting geographers.

It has at length been won, and the lecture by Commander Peary to the Royal Geographical Society, in the Albert Hall last night, told the story of the winning. The quest has been Commander Peary's one interest for twenty-four years; he has led four expeditions to reach the pole, after his remarkable exploration of the North Greenland ice-cap had given him the necessary experience, and had yielded him geographical results of perhaps greater scientific value than those of his last and most famous journey. He has carried through his work in an appropriately serious spirit. He has not regarded his quest as a mere matter of geographical athletics, but as a mission so important that he has been tempted to regard the Eskimo as placed by Providence in their inhospitable home on purpose to help him to his goal.

Commander Peary's lecture was a simple statement of the narrative of the expedition, and it gave no details as to the determination of the high latitudes, which geographers at this stage would have preferred to the short appendices giving the soundings and preliminary notes on the temperatures and tides. The expedition was apparently successful because a large force was able to start early in the season. Like Russia, according to Czar Nicholas, the pole has been protected by its ally, "General February"; but on this occasion the expedition began its journey from winter quarters in the middle of February. The party consisted of seven members, accompanied by seventeen Eskimos, I33 dogs, and nineteen sledges. With so large a staff a light advance party could be used to prepare the trail and successive divisions sent back from different stages, so that the final dash for the pole could be made by a party well equipped and comparatively fresh.

Commander Peary says that he and his comrades increased in fitness and training every day of the northern march. At a camp determined by Captain Bartlett as at $87^{\circ} 48^{\prime} \mathrm{N}$., that gallant officer and the last supporting party returned, leaving Peary, his negro servant Henson, and three Eskimo, with forty of the best dogs and five sledges. On April I Peary continued northward, hoping to reach the pole by five marches of twenty-five geographical miles each. At the end of the fifth march a temporary break in the clouds at "approximately local noon, Columbia meridian," enabled Peary to determine the position as $89^{\circ} 5 \tau^{\prime}$. A few hours later, with a light sledge carrying only instruments, drawn by a double team of dogs, he went on for another ten miles, and, as the sky cleared, he took observations, which showed that he had gone beyond the pole. After returning to camp he went eastward for eight miles, and both then and after his second return to camp he secured more observations, which confirmed his faith that he had reached and crossed the pole. Five miles from the pole he found a crack, and through a hole in it bored with a pickaxe he took a sounding of $\mathrm{r}_{5} \mathrm{Oo}$ fathoms, and found no bottom. The expedition returned south by forced marches, and it reached Cape Columbia in such fine trim that it crossed to Cape Hecla, and thence to the ship, in two marches of forty-five miles each.

The only definite scientific contributions announced are the soundings, which indicated a depth of only 3 Io fathoms at $85^{\circ} 23^{\prime}$; the depth had increased to more than 700 fathoms at ten miles further north, while at $87^{\circ}$ I $5^{\prime}$ the result was 1260 fathoms, with no NO. 2 I I 4, VOL. 83] 
bottom. Further soundings were prevented by the loss of the wire, which broke on two occasions, detachable sinkers not having been employed.

The expedition gives convincing proof that the sea extends over the North Pole, confirming the view of the eighteenth-century whalers, who claimed to have occasionally found such open seas that they were able to attain high latitudes. So many British whaiers claimed to have reached $82^{\circ}$ and $83^{\circ}$ in open water that it is difficult to disbelieve them all; and as the Greenland Sea was then being scoured by whalers, it is quite probable that they were occasionally able to attain these latitudes. The view that the sea extended to the pole was then partly based on the evidence of Dutch ships, that are said to have reached latitudes of $86^{\circ}, 88^{\circ}$, and $89^{\circ}$; but the evidence for these latitudes was found unconvincing when it was discussed by Barrington in 1774 .

Considering the exceptional interest in the achievement, and the impossibility of leaving any permanent record at the pole, Commander Peary's observations when published will, no doubt, be scanned critically, though in no hostile spirit. As Captain Bartlett accompanied him to $87^{\circ} 48^{\prime}$-about $1_{50}$ statute miles from the pole-and Peary thence made five long marches northward, there seems no reason why so expert an ice traveller, prepared to make the supreme effort of his life, should not have reached either the pole or sufficiently near it for all practical purposes.

As the great goal of Arctic enterprise has been won, we may now hope Arctic research will be continued in a more scientific spirit. There is much work still to be done. Geographically, the area now of most interest is that to the north-west of the Arctic Archipelago, and as Peary has shown that a large expedition can journey for four hundred miles out from land and back again, the search for the furthest islands of that group is possible by sledge journeys. The contour of the Arctic Ocean has still to be determined, and this work can hardly be done by sledge journeys, which can give but meagre results, compared with the work in a floating laboratory drifting, like the Fram, across the polar seas. Such work is slow, but the risks are probably not excessive. The Arctic deathrate has been far lower than the African, and, with the opportunities of life on a well-found ship, much of the biological and other scientific work might be done during the voyage. The reaching of the pole chould change the methods but not lessen the interest of Arctic work.

\section{Report and Conclusions on Peary's Arctic Work.}

A full report of the speech delivered by the Hon. J. Hampton Moore, of Pennsylvania, in the U.S. House of Representatives on March 22, with reference to Commander Peary's work in Arctic regions and his attainment of the North Pole, has lately been issued. The subjoined extracts from this report will serve to supplement the information which Commander Peary was able to give in his lecture last night, and to substantiate his claims to distinguished eminence as a polar explorer.

\section{Memorandum of Peary's Northern Voyages.}

1886. May to November; about seven months: Penetrated too miles on the inland ice of Greenland east of Disco Bay, about $70^{\circ} \mathrm{N}$. latitude; altitude, 7500 feet.

I891-2. June, I891, to September, 1892; about sixteen nonths : Right leg broken on voyage north. Five-hundredmile march out and same distance back, across northern part of Greenland, discovering Independence Bay on the north-eastern coast.

I 893-5. July, 1893, to September, 1895; about twentysoven months: Entire party except Peary and two men returned at end of first year. Spring of 1895 Peary repeated the march across northern end of Greenland, and sained some miles beyond his farthest of 1892 . Discovered the great Cape York meteorites, and brought the two smaller ones back with him.

1896. Juiy-October; about three months: Unsuccessful attempt to bring home largest of the Cape York meteorites.

I897. July-October; about three months: Brought home largest of the Cape York meteorites-the Alınigito, the largest in the world-weighing about 90 tons.

1898-1902. July, 1898, to October, 1902; about four years, three and a half months: During this time made four separate attempts to get north, resulting in the rounding of the northern end of Greenland and the attainment of the latitude of $83.59^{\circ}$ north of the extreme northern point of Greenland; also the attainment of the latitude of $84.17^{\circ}$ north of the northern point of Grant Land. All the instruments, records, private papers of the Lady Franklin expedition at Fort Conger brought home.

1905-6. July, 1905, to November, 1906; about seventeen months : Highest north, $87^{\circ} 6^{\prime}$, attained in this journey.

1908-9. July, 1908, to September, 1909; about fifteeı months: Attainment of the Pole.

Summary.-Eight voyages, six attempts to reach the Pole, and some twelve years spent inside the Arctic Circle.

\begin{tabular}{|c|c|c|c|c|c|c|c|}
\hline & & & $\begin{array}{l}\text { Degrees } \\
\text { N. Lat. }\end{array}$ & & & & $\begin{array}{l}\text { Degrees } \\
\text { N. Lat. }\end{array}$ \\
\hline & $\cdots$ & $\cdots$ & $69^{\circ} 00$ & 1900 & $\cdots$ & $\cdots$ & 83 \\
\hline I & $\cdots$ & $\ldots$ & $8 \mathrm{I} \cdot 35$ & 1902 & $\cdots$ & $\cdots$ & $84 \cdot 17$ \\
\hline 189 & ... & $\cdots$ & 8140 & 1906 & $\cdots$ & & $87^{\circ} 60$ \\
\hline 18 & $\cdots$ & $\ldots$ & $81 \cdot 50$ & 1909 & $\ldots$ & $\ldots$ & $90 \cdot 00$ \\
\hline
\end{tabular}

Peary's ability as a commander is thoroughly demonstrated by the success of his various expeditions. Twice his ship was driven through the ice to the highest point ever reached in the western hemisphere, and to a point higher than any ship has ever attained under her own steam. Many other ships attempted this same voyage; four of them accomplished part of it, and two were lost. As to his work being civil and distinct from naval, it may be observed that Prary's bringing of the Roosevelt home in the autumn of 1906, fighting her way through the heavy Arctic ice, from Cape Union to Littleton Island, and thence down along the savage Baffin Land and Labrador coasts, encountering storm after storm, with rudder and sternposts torn away, propellers crippled, and pumps going constantly, has been characterised as one of the ablest, most resourceful, and courageous affairs of its kind in the annals of Arctic exploration. Indeed, it was the wonder of everyone who saw the ship when it was taken out on the dry dock.

With regard to the expedition that was successful, the expedition of $1908-9$, resulting in the discovery of the Pole, he fitted out this expedition at his own expense and that of his friends, and was then granted leave of absence by the Navy Department, taking with him instructions which gave him an unqualified official connection with the Government.

Upon Commander Peary's return, the Navy Department asked the Coast and Geodetic Survey to furnish the results of the late expeditions carried on by him under the auspices of the Peary Arctic Club.

In reply to this request, Commander Peary sent a profile of soundings taken by the expedition, and tidal and meteorological records.

The following table shows the soundings from Cape Columbia to the Pole :-

$$
\text { Sounding by- Latitude Fathoms Remarks. }
$$

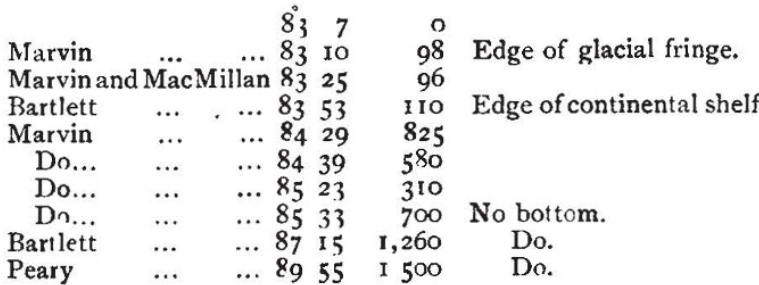

\section{Peary's Notes on Soundings.}

The sounding equipment of the expedition consisted of two reels of specially made piano-wire of 1000 fathoms each, and three approximately $20-1 \mathrm{~b}$. leads, with clam-shell device for grasping samples of the bottom. These reels were arranged to be fitted quickly to the upstanders of a 
sledge when making a sounding, and had handles for reeling in the wire and lead.

One of these reels and leads were carried by Bartlett with his advance party, and the other reel and two leads by the main party.

Portions of the wire and the two leads were lost at various times in hauling up, owing, probably, to kinks in the wire.

When the sounding at $85^{\circ} 33^{\prime}$ was made, 700 fathoms only were left of the sounding wire of the main party, and Bartlett, with the orher thousand fathoms, was in advance and inaccessible.

In hauling up the wire from this sounding it parted again, and some 200 fathoms, together with two pickaxe heads and a steel sledge shoe, which had been used to carry it down, were lost.

When Marvin turned back the Captain's rooo fathoms and the remaining 500 fathoms of the other reel were combined.

When Bartlett made the sounding at $87^{\circ}$ I $5^{\prime}$ I gave him explicit instructions to use the utmost caution in regard to the wire, in order not to lose any more of it, as I wanted it all for a sounding at the Pole should $I$ succeed in getting there.

Acting upon these instructions, Bartlett ran out 1260 fathoms and then stopped, on account of a small kink in the wire, which he feared would part when the wire was hauled up.

When I made my sounding about five miles from the Pole the wire parted, as had been feared, and the last lead and nearly all of the wire was lost:

The above facts are noted to explain the irregularity of these soundings, which did not get bottom.

The sounding of 3 ro fathoms at $85^{\circ} 23^{\prime}$ naturally impressed me at once as surprising, and when Marvin reported the result to me, immediately after taking the sounding, I at once asked him if he was sure that he had the bottom, and he replied that he was, as the fact of this pronounced shoaling from 825 fathoms to 310 impressed him at once, and he made sure that his depth was correct.

Again, when the sounding of 700 fathoms and no bottom was made about ten miles farther north, we both spoke of the peculiar fact of this outlying ridge with deeper channel intervening between it and the continental shelf, and Marvin again said that he was sure of his 310 fathoms reading.

Had it not been for the loss of the last lead and practically all of the wire while making the soundings at the Pole, I should, on the return, have interpolated other soundings.

The profile indicates that a line of 5 -mile interval soundings from Cape Columbia to the eighty-sixth parallel might develop a particularly interesting profile of the bottom of the Arctic Ocean.

\section{Tidal Records.}

The tidal records consist of practically unbroken series of hourly readings of the height of the tide, taken day and night, at the following places and between the dates specified :-

Station.

Perind of observation.

Length record.

Cape Sheridan. November 12, 1908, to June 30, 1909 Days. (total losi of record, 3I hours) $\ldots \quad 23 I$ Cape Columbia Novemher 16, 1908, to December 14, $1908 \ldots \quad \ldots \quad \ldots \quad \ldots \quad \ldots$

Cape Bryant ... January 16,1909, in February ${ }_{13}, 1909$ Fort Conger ... June 10, rgog, to June 25, 1909 (total loss of record, 5 hours) $\ldots$...

The observations were taken day and night, and besides the regular hourly readings numerous additional readings were generally taken near the times of the high and the low waters.

Commander Peary's observations leave little to be desired in regard to tidal observations between Cape Morris Jesup and Cape Columbia; but there are long stretches of the Arctic coast where nothing is available. This is especially true of the Russian coast and the western and northern portions of the Arctic archipelago.

The results obtained from Commander Peary's records show that the tides along the northern coasts of Grant Land and Greenland are quite different in many respects from what had been heretofore supposed. For example, his records prove that the tide occurs three hours earlier at Cape Columbia than at Cape Sheridan, and not later, as had been generally assumed.

As already intimated, the full significance of these observations in respect to Arctic geography cannot be seen at this time.

The meteorological records consist of thermograms covering about 180 days, and barograms covering about 260 days.

\section{National Geographic Society's Investigation.}

At a meeting of the board of managers of the National Geographic Society, Wednesday morning, October 20, the records and observations and proof of Commander Robert E. Peary that he reached the Pole April 6, 1909, were submitted to the society.

The records and observations were immediately referred to the committee on research, with the direction that the chairman appoint a subcommittee of experts, of which he shall be a member, to examine said records and report on them to the board. Mr. Henry Gannett, chairman of the committee on research, immediately appointed as the other members of the committee Rear-Admiral Colby M. Chester, United States Navy, and O. H. Tittmann, superintendent of the United States Coast and Geodetic Survey.

In due course the board of managers of the National Geographic Society, at a meeting held at Hubbard Memorial Hall, Washington, D.C., November 4, 1909 , received the following report:-

The subcommittee to which was referred the task of examining the records of Commander Peary in evidence of his having reached the North Pole beg to report that they have completed their task.

Commander Peary has submitted to this subcommittee his original journal and records of observations, together with all his instruments and apparatus and certain of the most important of the scientific results of his expedition. These have been carefully examined by your subcommittee, and they are unanimously of the opinion that Commander Peary reached the North Pole on April 6, 1909.

They also feel warranted in stating that the organisation, planning, and management of the expedition, its cumpiete success, and its scientific results reflect the greatest credit on the ability of Commander Robert E. Peary, and render him worthy of the highest honours that the National Geographic Society can bestow upon him.

\section{Henry Gannt G.}

C. M. Chester.

O. H. Tittmann.

The foregoing report was unanimously approved.

Immediately after this action the following resolutions were unanimously adopted :-

"Whereas Commander Robert E. Peary has reached the North Pole, the goal sought for centuries; and

"Whereas this is the greatest geographical achievement that this society can have opportunity to honour: Therefore

"Resolved, That a special medal be awarded to Commander Peary."

\section{Time Records on Dash to Pole.}

Referring to the time occupied by Peary in his last dash to the Pole, Mr. Gilbert H. Grosvenor, director and editor of the National Geographic Society, says :-

"In view of the recent published statement by a Member of Congress doubting the distances travelled by Peary on his last northern sledge journey, I have gone to some trouble to obtain correct figures from the narrative of Peary's last and previous expeditions.

"Anyone who cares to take the time and trouble can verify these figures, and will find the following results :-

"Peary's average distance per march from Cape Columbia to where Bartlett turned back was 12.8 miles. Had it not been for the north wind two days, setting them back, this average would have been $13 \frac{2}{3}$ miles. Between two observations taken by Marvin the average of three marches was $16 \frac{2}{3}$ miles. Several of the marches were 20 miles. 
"His average, from the time Bartlett left him, to the Pole was 26 miles. His average on his return was 25.6 miles.

"For comparison with the above figures, as showing that these averages are not at all excessive, the following facts can be taken from the narrative of the last expedition and previous ones:-

"Peary's last two marches on the return, from Cape Columbia to the Roosevelt, were 45 miles each. On this and previous expeditions the journey from Cape Hecla to the Roosevelt, a distance of 45 to 50 miles, was made in one march. The distance from Cape Columbia to Hecla was also made on other occasions in one march. The march from the Roosevelt to Porter Bay, a distance of 35 miles, was repeatedly made in eight, ten, and twelve hours. MacMillan and Borup, returning from Cape Morris Jesup to the Roosevelt, made the distance of $25^{\circ}$ miles or more in eight marches, an average of over 3 I miles a march. Peary, in one of his earlier expeditions, made the distance from Cape Wilkes to Cape D'Urville, a distance of 65 to 70 miles, in one march $\mathrm{He}$ repeatedly made the march from Cape D'Urville to Cape Fraser, a distance of 40 miles, in one march, and in the winter of r899-Igoo travelled from Etah to a point in Robertson Bay, 60 miles distant, in less than twelve hours.

"On his return from Independence Bay to Bowdoin Bay, Peary averaged 20 miles a day for twenty-five successive marches; 2 10 miles in seven successive marches (an average of 30 miles a day), making the last march of 40 miles, all these with dogs not driven by Eskimo drivers.

"On more than one occasion in the fall of 1900 Peary's parties went from Lake Hazen to Fort Conger, both by the Bellows route and by the Black Vale route, distances either way of 50 miles overland, in one march. This after the sun had set for the winter.

"In February, 1899, before the sun returned, Peary (with both feet frozen six weeks before) sledged from Conger to Cape D'Urville, a distance of over 200 miles, in eleven marches, in an average temperature of $53^{\circ}$ below zero, an average of about 20 miles. In March of rgo2 he went from Cape Sabine to Fort Conger, a distance of 250 miles to 300 miles, as travelled, in twelve marches, an average of 21 to 25 miles, and later covered the same distance again in eleven marches, an average of 22 to 27 miles.

"In the history of polar exploration no one has had so much and such long-continued training in ice work as Peary; his speed is the result of long years of practice, resulting in great physical endurance and skill in the use of the sledge."

\section{NOTES.}

Elsewhere in this issue Prof. Bryan deals with some aspects of the remarkable aëroplane flight from London to Manchester accomplished by $M$. Paulhan on April 27-28, thereby winning the prize of $10,000 l$. offered by the Daily Mail to the aviator who would make this cross-country flight within twenty-four hours. M. Paulhan left London (Hendon) at 5.22 p.m. on April 27, and descended at Lichfield- $x 17$ miles distant-at 8.10 p.m., that is, $2 \mathrm{~h} .48 \mathrm{~m}$. later. He left Lichfield at 4.to a.m. on the following day, and arrived at Manchester at 5.30 a.m., the distance being 69 miles. The total distance covered with the one stop was thus 186 miles. The prize was presented to $M$. Paulhan at a luncheon given in his honour on Saturday, and a roo-guinea cup was handed to Mr. Grahame-White in recognition of his plucky endeavour to secure the prize for England. At the banquet, the editor of the Daily Mail, in expressing regret for the absence of Lord Northcliffe on account of illness, reminded the assembly that it was owing to Lord Northcliffe's personal initiative that the substantial prize won by $\mathrm{M}$. Paulhan was offered for competition. He stated also that, in view of the great importance of aviation to Great Britain, the Daily Mail will immediately offer a further sum of $10,000 l$. for a flight of which the conditions will be announced shortly. Mr. Grahame-White, in acknowledging the toast of his health, said that it is his intention to expend the proceeds of the Royal Aëro Club's testimonial to himself upon the necessary organisation for an aëroplane flight from London to Paris "which I have made up my mind to attempt with the least possible delay." Though we have no sympathy with mere record-breaking, such flights as those accomplished across country by $\mathrm{M}$. Paulhan and $\mathrm{Mr}$. GrahameWhite, and others now contemplated, provide practical demonstrations of aëroplane performances which will make the British people realise more than anything else the possibilities of aërial navigation. At present the man in the machine counts for everything; and an aëroplane which Prof. Bryan considers to be laterally unstable is so skilfully managed that it rises superior to its imperfections. It is indeed a sign of progress in the management of aëroplanes that, without a trial flight, and about nine hours after his machine arrived at Hendon, M. Paulhan should make a flight of II7 miles across country without a stop. No doubt much yet remains to be done before the best type of construction of aëroplanes can be determined; nevertheless, the flight last week will go down in history as a notable achievement.

It is announced that Mr. P. H. Cowell, F.R.S., chief assistant in the Royal Observatory, Greenwich, has been appointed superintendent of the Nautical Almanac, in succession to Dr. A. M. W. Downing, who has retired.

WE have received with regret the announcement of the death, on April 28, of Prof. E. J. L. M. van Beneden, professor of zoology and comparative anatomy in the University of Liége, at sixty-four years of age.

A conversazione, with short lectures and lantern demonstrations, will be held by the Entomological Society in the rooms of the Civil Service Commission, Burlington Gardens, W., on the evening of Friday, May 27. Fellows of the society and others interested requiring further particulars are invited to address all inquiries to the honorary secretary, conversazione committee, II Chandos Street, Cavendish Square, W.

THE valuable collections of native African art made by Mr. E. Torday in the southern Belgian Congo are now being classified and arranged by the authorities of the British Museum. The most remarkable specimens in the collection are the wooden portrait statues of past rulers, which throw a new light on savage art in Africa. Next in importance are a splendid carved throne of the paramount chiefs, wooden caskets and cups, and specimens of remarkable textiles resembling velvet, made from the fibre of the upper skin of the palm leaf (raphia). This collection was happily made before the almost complete disappearance of native art work due to the importation of cheap European productions.

THE council of the Institution of Civil Engineers has made the following awards for papers during the session 1909-10:- -a Telford gold medal to Mr. C. M. Jacobs (New York) ; a Watt gold medal to Mr. J. D. Watson (Birmingham); a George Stephenson gold medal to Mr. D. A. Matheson (Glasgow); Telford premiums to Messrs. F. C. Buscarlet (Sunderland), A. Hunter (Glasgow), I. C. Barling (Tynemouth), J. Dalziel and J. Sayers (Derby), and J. Shaw (Birkenhead); and the Manby premium to the late Mr. C. W. Hodson (London). The thanks of the council have been conveyed to their colleague, Dr. C. A. Harrison, for the paper contributed by him. 